\section{Effect of an Italian propolis on the growth of Listeria monocytogenes, Staphylococcus aureus and Bacillus cereus in milk and whey cheese}

Francesca Pedonese, Giada Verani, Beatrice Torracca, Barbara Turchi, Antonio Felicioli, Roberta Nuvoloni Department of Veterinary Sciences, University of Pisa, Italy

\begin{abstract}
Propolis antimicrobial activity has been limitedly studied in food, particularly in dairy products. We studied the antimicrobial activity of an alcoholic extract of an Italian propolis in sterile skim milk, pasteurized cow's milk, and cow's and goat's whey cheese (ricotta). Following the determination of the minimal inhibitory concentration on Gram+ and Gram- bacteria, the extract was employed at 2 and 5\% (P2, P5), using controls with the same ethanol concentrations (E2, E5) and without any addition. In milk trials, Listeria monocytogenes, Staphylococcus aureus, Bacillus cereus, and Pseudomonas fluorescens were tested. P2 and P5 samples registered significant decreases of Gram+ bacteria in skim milk. The same was true for P5 in cows' milk, but only with $S$. aureus for P2. Ricotta was inoculated with L. monocytogenes, $S$ aureus and $B$. cereus and stored at $8.5^{\circ} \mathrm{C}$. In cow's milk ricotta, L. monocytogenes counts in P5 were always lower than control during the storage time, significantly so from the $14^{\text {th }}$ day. In goat's ricotta, L. monocytogenes counts in P5 were at least one logarithm lower than E5, whereas the extract didn't show a significant effect on $S$. aureus and B. cereus. The antimicrobial activity of propolis, particularly on $L$. monocytogenes, could be employed in ready-to-eat refrigerated dairy products.
\end{abstract}

\section{Introduction}

Among beehive products, propolis is a complex material, collected by honeybees from plant buds and exudates and enriched by beeswax and bee secretions (Zabaiou et al., 2017). It has been used in folk medicine for centuries and its beneficial effects are well known (Sforcin and Bankova, 2011) and attributed to a variety of active compounds, including flavonoids (Huang et al.,
2014).

A promising area of propolis use involves its application as a preservative in different foods, especially fruit juices, fruits and vegetables, due to its antimicrobial and antioxidative properties (Bankova et al., 2016). Though the antimicrobial effect of propolis has been extensively studied (Banskota et al., 2001; De Vecchi and Drago, 2007), knowledge about its antimicrobial activity in food of animal origin is quite limited and mostly focused on meat and fish products, where beneficial antimicrobial effects (mainly decrease of mesophilic and psychrotrophic counts) are reported in beef patties, sausages, filleted and minced fish meat (Pobiega et al., 2019). There are only few studies about milk and/or dairy products and they are focused on some specific applications of the propolis antimicrobial properties (shelf-life of cheese: Metwalli, 2011; L. monocytogenes in refrigerated milk: Thamnopoulos et al., 2018). With the aim to increase knowledge about practical effects of propolis in milk and dairy products, we evaluated the antimicrobial activity of an Italian propolis against food microorganisms in milk at optimum growth temperature and investigated the antimicrobial effects on L. monocytogenes, Staphylococcus aureus and Bacillus cereus in a refrigerated ready-toeat dairy product (ricotta), commonly consumed and potentially exposed to thermal abuse.

\section{Materials and Methods}

\section{Propolis and ethanolic extract preparation}

Propolis was collected in Val di Cecina (Tuscany, 50-450 $\mathrm{m}$ above sea level) in a single harvesting season. Pollen analysis of propolis was carried out following Ricciardelli D'Albore (1979). Raw propolis was stored at $-20^{\circ} \mathrm{C}$, finely ground, extracted with $70 \%$ ethanol $(10 \mathrm{~g}$ in $100 \mathrm{ml})$ and repeatedly submitted to refrigerated centrifugation ( $9000 \mathrm{rpm}, 15 \mathrm{~min}$ ) and filtration phases, after being frozen at $-20^{\circ} \mathrm{C}$, to remove insoluble waxes. On the obtained ethanolic extract of propolis (EEP), flavonoids quantification and determination of dry residue content were performed according to Popova et al. (2004) and Baldini et al. (1996), respectively.

\section{Bacterial cultures}

Overall, 7 different microorganisms of relevance for food safety and quality were studied, 4 Gram + (L. monocytogenes ATCC 7644, S. aureus ATCC 25923, S. aureus
Correspondence: Francesca Pedonese, Department of Veterinary Sciences, University of Pisa, Viale delle Piagge 2, 56124 Pisa, Italy.

Tel.: +39.050-2216707 - Fax: +39-050-2210654

E-mail: francesca.pedonese@unipi.it.

Key words: Propolis, Listeria monocytogenes, Staphylococcus aureus, Bacillus cereus, Dairy.

Conflict of interest: The authors declare no potential conflict of interest.

Funding: this research was funded by Pisa University grants (Fondi di Ateneo).

Received for publication: 17 January 2019.

Revision received: 6 August 2019.

Accepted for publication: 28 August 2019.

This work is licensed under a Creative Commons Attribution-NonCommercial 4.0 International License (CC BY-NC 4.0).

CCopyright: the Author(s), 2019

Licensee PAGEPress, Italy

Italian Journal of Food Safety 2019; 8:8036

doi:10.4081/ijfs. 2019.8036

ATCC 35556, high biofilm-producer, $B$. cereus DSV12, a wild strain of food origin) and 3 Gram- (Salmonella enterica serovar Typhimurium ATCC 14028, Escherichia coli ATCC 25922, Pseudomonas fluorescens ATCC 13525). For milk and whey cheese trials, those showing the highest in vitro susceptibility to EEP in preliminary tests were chosen.

\section{Antimicrobial disk susceptibility test}

The test was made according to CLSI (2013), using Tryptone Soy Agar (TSA, Oxoid, Basingstoke, UK), a bacterial inoculum of 0.5 McFarland turbidity and sterile filter paper disks with $10 \mu \mathrm{L}$ each of EEP, $70 \%$ ethanol and dimethyl sulfoxide (DMSO); the inhibition zone diameters were determined after 24 hours of incubation at $25^{\circ} \mathrm{C}$ (pseudomonads) and $37^{\circ} \mathrm{C}$ (other bacteria).

\section{Minimal inhibitory concentration} and minimal bactericidal concentration determination assay

MIC values (the lowest concentration that inhibits visible microbial growth) were determined for EEP and $70 \%$ ethanol following Wiegand et al. (2008) with minor modifications. The assay was performed in microtiter plates using $10 \mu \mathrm{L}$ of bacterial inoculum and $190 \mu \mathrm{L}$ of each dilution. EEP was diluted in DMSO (1:3) and two-fold dilutions from $1 / 8$ to $1 / 16,384$ were prepared in Tryptone Soy Broth (Oxoid). For 
the bacterial inoculum an overnight broth culture of each microorganism, spectrophotometrically adjusted at about $1.5 \times 10^{8}$ $\mathrm{cfu} / \mathrm{mL}$, was used. The microplates were incubated at $25^{\circ} \mathrm{C}$ (pseudomonads) and $37^{\circ} \mathrm{C}$ (other bacteria) for 24 hours. For MBC assay, a loopful from MIC and higher dilutions wells was inoculated onto TSA, with the same incubation, and the lowest concentration with no growth was considered as the MBC value. MIC/MBC assays were made in triplicate.

\section{Quantification of EEP and ethanol effect on bacterial growth in milk}

Bacterial growth was tested in sterilized skim milk (Skim Milk Powder, Oxoid) and in cow's milk, pasteurized at $63^{\circ} \mathrm{C}$ for 30 minutes. Total bacterial counts were determined in Plate Count Agar (Oxoid) at $30^{\circ} \mathrm{C}$ for 72 hours before and after milk pasteurization. An overnight culture of each microorganism (the Gram+ ones and P. fluorescens) was inoculated at $1 \%$ in each type of milk with $2 \%$ EEP (P2), 5\% EEP (P5), $2 \%$ ethanol (E2), 5\% ethanol (E5) and in milk alone (control). After 24 hours at $37^{\circ} \mathrm{C}$ $\left(25^{\circ} \mathrm{C}\right.$ for $P$. fluorescens), bacterial counts were determined on the following media (Oxoid): Listeria Selective Agar Base with Oxford Supplement for L. monocytogenes (Heo et al., 2014), Baird Parker Agar with
Egg Yolk-Tellurite for coagulase-positive staphylococci (UNI, 2004), Mannitol Egg Yolk Polymixin Agar for B. cereus (FDA BAM, 2017), Pseudomonas Agar Base with CFC Supplement for P. fluorescens (Chiesa et al., 2014).

\section{Quantification of EEP and ethanol effect on bacterial growth in whey cheese}

Bacterial growth was tested in an industrial cow's whey cheese and in an artisanal goat's one, purchased at the beginning of shelf-life, at retail level and directly from the producer, respectively, and immediately inoculated. P2, P5, E2, E5 and control samples were prepared and inoculated with a pool inoculum of 4 chosen microorganisms (the Gram+ ones). Before mixing, the concentration of each microorganism was spectrophotometrically adjusted in saline solution at about $1.5 \times 10^{8} \mathrm{cfu} / \mathrm{mL}$. The final inoculum was used at $1 \%$ in ricotta. Control samples without inocula were tested to exclude the presence of $L$. monocytogenes, $S$. aureus and B. cereus. Ricotta samples were stored at $8.5 \pm 0.5^{\circ} \mathrm{C}$ for 28 and 14 days, for cow's and goat's product, respec-

Table 1. Minimal inhibitory concentration (MIC) and Minimal Bactericidal Concentration $(\mathrm{MBC})$ values $(\mathrm{mg} / \mathrm{mL})$ of propolis ethanolic extract and ethanol against the tested microorganisms.

\begin{tabular}{|c|c|c|c|c|}
\hline & M & & & \\
\hline & EEP & Ethanol & EEP & Ethano] \\
\hline L.m. 7644 & 1.78 & 13.91 & 7.11 & 55.63 \\
\hline S.a. 25923 & 0.89 & 13.91 & 3.55 & 55.63 \\
\hline S.a. 35556 & 1.78 & 13.91 & 3.55 & 55.63 \\
\hline B.c. DSV12 & 0.89 & 13.91 & 3.55 & 55.63 \\
\hline S.T. 14028 & 3.55 & 13.91 & 28.44 & 55.63 \\
\hline E.c. 25922 & 3.55 & 13.91 & 7.11 & 55.63 \\
\hline Pff 13525 & 1.78 & 13.91 & 28.44 & 55.63 \\
\hline
\end{tabular}

EEP: ethanolic extract of propolis. L.m.: Listeria monocytogenes; S.a.: Staphylococcus aureus; B.c.: Bacillus cereus; S.T.: Salmonella enterica serovar Typhimurium; E.c.: Escherichia coli; P.f.: Pseudomonas fluorescens. Results are the mode of three independent trials.

Table 2. Growth of the tested microorganisms in milk with different percentages of propolis ethanolic extract and ethanol.

\begin{tabular}{|c|c|c|c|c|c|}
\hline & P2 & P5 & E2 & E5 & C \\
\hline \multicolumn{6}{|c|}{ Skim milk } \\
\hline L.m. 7644 & $\begin{array}{c}6.40 \pm 0.48^{\mathrm{b}} \\
(-1.87)\end{array}$ & $\begin{array}{c}3.92 \pm 0.14 c \\
(-4.35)\end{array}$ & $\begin{array}{c}8.04 \pm 0.19^{\mathrm{a}} \\
(-0.23)\end{array}$ & $\begin{array}{c}7.50 \pm 0.34 \mathrm{a}^{\mathrm{a}} \\
(-0.77)\end{array}$ & $8.27 \pm 0.07^{\mathrm{a}}$ \\
\hline S.a. 25923 & $\begin{array}{c}5.98 \pm 0.50^{\mathrm{b}} \\
(-1.98)\end{array}$ & $\begin{array}{c}5.31 \pm 0.26^{\mathrm{b}} \\
(-2.65)\end{array}$ & $\begin{array}{c}7.84 \pm 0.16^{\mathrm{a}} \\
(-0.12)\end{array}$ & $\begin{array}{c}7.46 \pm 0.07^{\mathrm{a}} \\
(-0.50)\end{array}$ & $7.96 \pm 0.08^{\mathrm{a}}$ \\
\hline S.a. 35556 & $\begin{array}{c}5.74 \pm 0.33^{b} \\
\quad(-2.63)\end{array}$ & $\begin{array}{c}5.33 \pm 0.42^{b} \\
(-3.04)\end{array}$ & $\begin{array}{c}8.19 \pm 0.05^{\mathrm{a}} \\
(-0.18)\end{array}$ & $\begin{array}{c}8.09 \pm 0.13^{\mathrm{a}} \\
(-0.28)\end{array}$ & $8.37 \pm 0.08^{\mathrm{a}}$ \\
\hline B.c. DSV12 & $\begin{array}{c}3.31 \pm 0.35^{b} \\
(-2.72)\end{array}$ & $\begin{array}{c}2.94 \pm 0.32^{b} \\
(-3.09)\end{array}$ & $\begin{array}{c}6.57 \pm 0.92^{\mathrm{a}} \\
(+0.54)\end{array}$ & $\begin{array}{c}6.86 \pm 0.24^{\mathrm{a}} \\
(+0.83)\end{array}$ & $6.03 \pm 0.44^{a}$ \\
\hline P.f. 13525 & $\begin{array}{c}6.78 \pm 0.11^{\mathrm{c}} \\
(-1.09)\end{array}$ & $\begin{array}{c}6.55 \pm 0.07^{\mathrm{c}} \\
(-1.32)\end{array}$ & $\begin{array}{c}7.45 \pm 0.41^{\mathrm{ab}} \\
(-0.42)\end{array}$ & $\begin{array}{c}6.95 \pm 0.20^{\mathrm{bc}} \\
(-0.92)\end{array}$ & $7.87 \pm 0.18^{a}$ \\
\hline \multicolumn{6}{|c|}{ Pasteurized cow's milk } \\
\hline L.m. 7644 & $\begin{array}{c}5.59 \pm 0.31^{\mathrm{a}} \\
(-0.47)\end{array}$ & $\begin{array}{c}4.66 \pm 0.22^{\mathrm{b}} \\
(-1.40)\end{array}$ & $\begin{array}{c}5.79 \pm 0.45^{\mathrm{a}} \\
(-0.27)\end{array}$ & $\begin{array}{c}5.82 \pm 0.14^{\mathrm{a}} \\
(-0.24)\end{array}$ & $6.06 \pm 0.31^{\mathrm{a}}$ \\
\hline S.a. 25923 & $\begin{array}{c}6.30 \pm 0.16^{c} \\
(-1.12)\end{array}$ & $\begin{array}{c}5.09 \pm 0.13^{\mathrm{d}} \\
(-2.33)\end{array}$ & $\begin{array}{c}7.10 \pm 0.31^{\mathrm{ab}} \\
(-0.32)\end{array}$ & $\begin{array}{c}6.62 \pm 0.27^{\mathrm{bc}} \\
(-0.80)\end{array}$ & $7.42 \pm 0.21^{\mathrm{a}}$ \\
\hline S.a. 35556 & $\begin{array}{c}7.04 \pm 0.35^{\mathrm{a}} \\
(-0.67)\end{array}$ & $\begin{array}{c}4.49 \pm 0.09^{\mathrm{b}} \\
(-3.22)\end{array}$ & $\begin{array}{c}7.44 \pm 0.43^{\mathrm{a}} \\
(-0.27)\end{array}$ & $\begin{array}{c}7.13 \pm 0.36^{\mathrm{a}} \\
(-0.58)\end{array}$ & $7.71 \pm 0.32^{\mathrm{a}}$ \\
\hline B.c. DSV12 & $\begin{array}{c}6.21 \pm 0.27 \mathrm{a}^{\mathrm{a}} \\
(0.24)\end{array}$ & $\begin{array}{c}3.12 \pm 0.56^{\mathrm{b}} \\
(-2.85)\end{array}$ & $\begin{array}{c}5.75 \pm 0.28 \mathrm{a}^{\mathrm{a}} \\
(-0.22)\end{array}$ & $\begin{array}{c}6.25 \pm 0.21 \mathrm{a}^{\mathrm{a}} \\
(0.28)\end{array}$ & $5.97 \pm 0.47^{\mathrm{a}}$ \\
\hline P.f. 13525 & $\begin{array}{c}7.32 \pm 0.20 \\
(0.17)\end{array}$ & $\begin{array}{c}6.98 \pm 0.24 \\
(-0.17)\end{array}$ & $\begin{array}{c}7.18 \pm 0.36 \\
(0.03)\end{array}$ & $\begin{array}{c}6.89 \pm 0.42 \\
(-0.26)\end{array}$ & $7.15 \pm 0.16$ \\
\hline
\end{tabular}

P2: milk with $2 \%$ propolis ethanolic extract; P5: milk with 5\% propolis ethanolic extract; E2: milk with 2\% ethanol (70\%); E5: milk with 5\% ethanol (70\%); C: control (milk). L.m.: Listeria monocytogenes; S.a. Staphylococcus aureus; B.c.: Bacillus cereus; P.f.: Pseudomonas fluorescens. Results are mean values of three independent trials \pm standard deviation. In brackets: difference in bacterial counts in comparison with the corresponding control. Values are expressed in $\log \mathrm{cfu} / \mathrm{mL}$. abc Different letters in the same row denote significant differences $(\mathrm{P}<0.05)$. 
tively, based on their shelf-life and analyzed immediately after inoculation ( $\mathrm{t} 0$ ) and weekly (t7, t14, t21, t28) to quantify the different microorganisms, as described for milk tests.

\section{Statistical analysis}

For each microorganism and substrate (milk and whey cheeses) one-way ANOVA and Tukey HSD test for post-hoc comparisons were performed ( $\mathrm{R}$ software v. 3.5.0, $\mathrm{R}$ Foundation for Statistical Computing,
Vienna, Austria), to evaluate the differences in bacterial counts at each time, considering the sample type (P2, P5, E2, E5, C) as factor. Differences were considered statistically significant with $\mathrm{P}$ value $<0.05$.

Table 3. Growth of the tested microorganisms in cow's and goat's whey cheese with different percentages of propolis ethanolic extract and ethanol during storage.

\begin{tabular}{|c|c|c|c|c|c|c|}
\hline & & P2 & P5 & E2 & $\mathbf{E 5}$ & C \\
\hline \multicolumn{7}{|c|}{ Cow's whey cheese } \\
\hline \multirow[t]{5}{*}{ L.m. 7644} & to & $\begin{array}{c}5.48 \pm 0.43 \\
(-0.11)\end{array}$ & $\begin{array}{c}5.58 \pm 0.28 \\
(-0.01)\end{array}$ & $\begin{array}{c}5.59 \pm 0.34 \\
(0.00)\end{array}$ & $\begin{array}{c}5.50 \pm 0.32 \\
(-0.09)\end{array}$ & $5.59 \pm 0.27$ \\
\hline & $\mathrm{t} 7$ & $\begin{array}{c}6.53 \pm 1.66 \\
(-0.67)\end{array}$ & $\begin{array}{c}5.38 \pm 0.36 \\
(-1.82)\end{array}$ & $\begin{array}{c}6.06 \pm 0.40 \\
(-1.14)\end{array}$ & $\begin{array}{c}5.39 \pm 0.92 \\
(-1.81)\end{array}$ & $7.20 \pm 0.89$ \\
\hline & $\mathrm{t} 14$ & $\begin{array}{c}7.30 \pm 0.74^{\mathrm{a}} \\
(0.00)\end{array}$ & $\begin{array}{c}5.02 \pm 0.24^{\mathrm{b}} \\
(-2.28)\end{array}$ & $\begin{array}{c}7.32 \pm 0.02^{\mathrm{a}} \\
(0.02)\end{array}$ & $\begin{array}{c}5.79 \pm 0.12^{\mathrm{ab}} \\
\quad(-1.51)\end{array}$ & $7.30 \pm 0.74^{\mathrm{a}}$ \\
\hline & $\mathrm{t} 21$ & $\begin{array}{c}7.12 \pm 0.91^{\mathrm{ab}} \\
(-1.01)\end{array}$ & $\begin{array}{c}4.87 \pm 0.21^{\mathrm{b}} \\
(-3.26)\end{array}$ & $\begin{array}{c}7.67 \pm 0.19^{\mathrm{a}} \\
(-0.46)\end{array}$ & $\begin{array}{c}6.45 \pm 1.06^{\mathrm{ab}} \\
(-1.68)\end{array}$ & $8.13 \pm 0.10^{\mathrm{a}}$ \\
\hline & $\mathrm{t} 28$ & $\begin{array}{c}7.71 \pm 0.08^{\mathrm{a}} \\
(-0.51)\end{array}$ & $\begin{array}{c}4.53 \pm 0.48^{\mathrm{b}} \\
(-3.69)\end{array}$ & $\begin{array}{c}7.99 \pm 0.17^{\mathrm{a}} \\
(-0.23)\end{array}$ & $\begin{array}{c}6.86 \pm 0.96^{\mathrm{a}} \\
(-1.36)\end{array}$ & $8.22 \pm 0.18^{\mathrm{a}}$ \\
\hline \multirow[t]{5}{*}{ S.a. $25923 / 35556$} & to & $\begin{array}{c}5.41 \pm 0.08 \\
(0.04)\end{array}$ & $\begin{array}{c}5.36 \pm 0.04 \\
(-0.01)\end{array}$ & $\begin{array}{c}5.43 \pm 0.01 \\
(0.06)\end{array}$ & $\begin{array}{c}5.25 \pm 0.10 \\
(-0.12)\end{array}$ & $5.37 \pm 0.10$ \\
\hline & $\mathrm{t} 7$ & $\begin{array}{c}4.75 \pm 0.20 \\
(-0.10)\end{array}$ & $\begin{array}{c}4.56 \pm 0.45 \\
(-0.29)\end{array}$ & $\begin{array}{c}4.97 \pm 0.38 \\
(0.12)\end{array}$ & $\begin{array}{c}4.88 \pm 0.21 \\
(0.03)\end{array}$ & $4.85 \pm 0.16$ \\
\hline & $\mathrm{t} 14$ & $\begin{array}{c}4.38 \pm 0.51 \\
(0.00)\end{array}$ & $\begin{array}{c}3.81 \pm 1.11 \\
(-0.57)\end{array}$ & $\begin{array}{c}4.81 \pm 0.32 \\
(0.43)\end{array}$ & $\begin{array}{c}4.58 \pm 0.03 \\
(0.20)\end{array}$ & $4.38 \pm 0.35$ \\
\hline & $\mathrm{t} 21$ & $\begin{array}{c}4.27 \pm 0.65 \\
(-0.32)\end{array}$ & $\begin{array}{c}3.52 \pm 1.10 \\
(-1.07)\end{array}$ & $\begin{array}{c}4.73 \pm 0.12 \\
(0.14)\end{array}$ & $\begin{array}{c}4.38 \pm 0.03 \\
(-0.21)\end{array}$ & $4.59 \pm 0.15$ \\
\hline & $\mathrm{t} 28$ & $\begin{array}{c}4.29 \pm 0.91 \\
(0.18)\end{array}$ & $\begin{array}{c}3.34 \pm 0.80 \\
(-0.77)\end{array}$ & $\begin{array}{c}4.63 \pm 0.21 \\
(0.52)\end{array}$ & $\begin{array}{c}4.12 \pm 0.08 \\
(0.01)\end{array}$ & $4.11 \pm 0.38$ \\
\hline \multirow[t]{5}{*}{ B.c. DSV12 } & to & $\begin{array}{c}3.71 \pm 0.70 \\
(-0.04)\end{array}$ & $\begin{array}{c}3.68 \pm 0.68 \\
(-0.07)\end{array}$ & $\begin{array}{c}3.73 \pm 0.64 \\
(-0.02)\end{array}$ & $\begin{array}{c}3.61 \pm 0.73 \\
(-0.14)\end{array}$ & $3.75 \pm 0.65$ \\
\hline & $\mathrm{t} 7$ & $\begin{array}{c}1.57 \pm 0.98 \\
(-1.66)\end{array}$ & $\begin{array}{c}1.33 \pm 0.58 \\
(-1.90)\end{array}$ & $\begin{array}{c}3.37 \pm 0.58 \\
(0.14)\end{array}$ & $\begin{array}{c}2.71 \pm 0.98 \\
(-0.52)\end{array}$ & $3.23 \pm 0.46$ \\
\hline & $\mathrm{t} 14$ & $\begin{array}{c}1.35 \pm 0.49 \\
(-0.95)\end{array}$ & $\begin{array}{c}1.35 \pm 0.49 \\
(-0.95)\end{array}$ & $\begin{array}{c}2.44 \pm 1.05 \\
(0.14)\end{array}$ & $\begin{array}{c}2.00 \pm 0.43 \\
(-0.30)\end{array}$ & $2.30 \pm 0.85$ \\
\hline & $\mathrm{t} 21$ & $\begin{array}{c}1.00 \pm 0.00 \\
(-0.85)\end{array}$ & $\begin{array}{c}1.00 \pm 0.00 \\
(-0.85)\end{array}$ & $\begin{array}{c}1.35 \pm 0.49 \\
(-0.50)\end{array}$ & $\begin{array}{c}1.00 \pm 0.00 \\
(-0.85)\end{array}$ & $1.85 \pm 0.21$ \\
\hline & $\mathrm{t} 28$ & $\begin{array}{c}1.00 \pm 0.00 \\
(-0.57)\end{array}$ & $\begin{array}{c}1.00 \pm 0.00 \\
(-0.57)\end{array}$ & $\begin{array}{c}1.23 \pm 0.40 \\
(-0.33)\end{array}$ & $\begin{array}{c}1.57 \pm 0.51 \\
(0.00)\end{array}$ & $1.57 \pm 0.51$ \\
\hline \multicolumn{7}{|c|}{ Goat's whey cheese } \\
\hline \multirow[t]{3}{*}{ L.m. 7644} & to & $\begin{array}{c}5.37 \pm 0.18 \\
(-0.09)\end{array}$ & $\begin{array}{c}5.40 \pm 0.21 \\
(-0.06)\end{array}$ & $\begin{array}{c}5.41 \pm 0.25 \\
(-0.05)\end{array}$ & $\begin{array}{c}5.45 \pm 0.22 \\
(-0.01)\end{array}$ & $5.46 \pm 0.29$ \\
\hline & $\mathrm{t} 7$ & $\begin{array}{c}7.00 \pm 0.11^{\mathrm{a}} \\
(-0.10)\end{array}$ & $\begin{array}{c}5.44 \pm 0.28^{\mathrm{b}} \\
(-1.66)\end{array}$ & $\begin{array}{c}6.90 \pm 0.24^{\mathrm{a}} \\
(-0.21)\end{array}$ & $\begin{array}{c}6.86 \pm 0.31^{\mathrm{a}} \\
(-0.24)\end{array}$ & $7.10 \pm 0.08^{\mathrm{a}}$ \\
\hline & $\mathrm{t} 14$ & $\begin{array}{c}7.01 \pm 0.15^{\mathrm{ab}} \\
(-0.15)\end{array}$ & $\begin{array}{c}5.70 \pm 0.72^{\mathrm{b}} \\
(-1.46)\end{array}$ & $\begin{array}{c}7.06 \pm 0.14^{\mathrm{ab}} \\
(-0.10)\end{array}$ & $\begin{array}{c}6.97 \pm 0.18^{\mathrm{ab}} \\
(-0.19)\end{array}$ & $7.16 \pm 0.14^{\mathrm{a}}$ \\
\hline \multirow[t]{3}{*}{ S.a. $25923 / 35556$} & to & $\begin{array}{c}4.98 \pm 0.28 \\
(0.06)\end{array}$ & $\begin{array}{c}5.00 \pm 0.28 \\
(0.08)\end{array}$ & $\begin{array}{c}5.07 \pm 0.39 \\
(0.15)\end{array}$ & $\begin{array}{c}4.96 \pm 0.30 \\
(0.04)\end{array}$ & $4.92 \pm 0.23$ \\
\hline & $\mathrm{t} 7$ & $\begin{array}{c}5.10 \pm 0.19 \\
(-0.08)\end{array}$ & $\begin{array}{c}4.95 \pm 0.30 \\
(-0.23)\end{array}$ & $\begin{array}{c}5.25 \pm 0.31 \\
(0.07)\end{array}$ & $\begin{array}{c}5.11 \pm 0.10 \\
(-0.07)\end{array}$ & $5.18 \pm 0.03$ \\
\hline & $\mathrm{t} 14$ & $\begin{array}{c}5.08 \pm 0.08 \\
(0.05)\end{array}$ & $\begin{array}{c}4.87 \pm 0.24 \\
(-0.16)\end{array}$ & $\begin{array}{c}5.16 \pm 0.23 \\
(0.13)\end{array}$ & $\begin{array}{c}5.18 \pm 0.07 \\
(0.15)\end{array}$ & $5.03 \pm 0.02$ \\
\hline \multirow[t]{3}{*}{ B.c. DSV12 } & to & $\begin{array}{c}3.86 \pm 0.25 \\
(0.02)\end{array}$ & $\begin{array}{c}3.91 \pm 0.24 \\
(0.07)\end{array}$ & $\begin{array}{c}3.83 \pm 0.32 \\
(-0.01)\end{array}$ & $\begin{array}{c}3.65 \pm 0.36 \\
(-0.19)\end{array}$ & $3.84 \pm 0.26$ \\
\hline & $\mathrm{t} 7$ & $\begin{array}{c}3.04 \pm 0.80 \\
(0.03)\end{array}$ & $\begin{array}{c}2.27 \pm 0.38 \\
(-0.74)\end{array}$ & $\begin{array}{c}3.07 \pm 0.75 \\
(0.06)\end{array}$ & $\begin{array}{c}3.12 \pm 0.81 \\
(0.11)\end{array}$ & $3.01 \pm 0.38$ \\
\hline & $\mathrm{t} 14$ & $\begin{array}{c}1.00 \pm 0.00 \\
(-0.35)\end{array}$ & $\begin{array}{c}1.00 \pm 0.00 \\
(-0.35)\end{array}$ & $\begin{array}{c}1.35 \pm 0.49 \\
(0.00)\end{array}$ & $\begin{array}{c}1.00 \pm 0.00 \\
(-0.35)\end{array}$ & $1.35 \pm 0.49$ \\
\hline
\end{tabular}

P2: milk with 2\% propolis ethanolic extract; P5: milk with 5\% propolis ethanolic extract; E2: milk with 2\% ethanol (70\%); E5: milk with 5\% ethanol (70\%); C: control (milk). L.m.: Listeria monocytogenes; S.a.: Staphylococcus aureus; B.c.: Bacillus cereus. Results are mean values of two independent trials \pm standard deviation. In brackets: difference in bacterial counts in comparison with the corresponding control. Values are expressed in $\log \mathrm{cfu} / \mathrm{g}$. abcDifferent letters in the same row denote significant differences $(\mathrm{P}<0.05)$. 


\section{Results}

\section{Characterization of propolis and EEP}

Pollen analysis of propolis revealed a wide variety of pollen types. They were identified, according to Louveaux et al. (1978), as belonging to Castanea (27\% of total pollen), Hedera (10\%), and Coronilla/Hippocrepis, Olea f., Pinus f., Trifolium gr., Quercus gr., all in percentages of 4.5-7\%, with various Compositae, Umbelliferae and Graminaceae in lower quantities. A dry residue content of $8.44 \%$ and a flavonoids content of $2.3 \%(\mathrm{w} / \mathrm{w})$ was found in EEP.

\section{Antimicrobial activity of EEP}

Gram+ bacteria showed EEP inhibition zone diameters of $12 \mathrm{~mm}$ (L. monocytogenes), $13 \mathrm{~mm}$ (B. cereus) and 19-20 mm (S. aureus), higher than those of Gram- (10$11 \mathrm{~mm})$. Ethanol and DMSO did not inhibit any of the strains, except for a slight inhibition recorded for ethanol against $P$. fluorescens $(7 \mathrm{~mm})$ and $E$. coli $(8 \mathrm{~mm})$. As for EEP MIC (Table 1), values of 0.89-1.78 $\mathrm{mg} / \mathrm{mL}$ were obtained for Gram + bacteria, and in the range 1.78 (P. fluorescens)-3.55 $\mathrm{mg} / \mathrm{mL}$ for Gram-; ethanol values were ever $13.91 \mathrm{mg} / \mathrm{mL}$, showing that the predominant effect was exerted by propolis compounds. EEP MBC values for Gram+ were $3.55-7.11 \mathrm{mg} / \mathrm{mL}$, and $7.11-28.44 \mathrm{mg} / \mathrm{mL}$ for Gram-, with ethanol values of 55.63 $\mathrm{mg} / \mathrm{mL}$.

\section{Effect of EEP and ethanol on bacter- ial growth in milk}

As shown in Table 2, P2 and P5 determined in skim milk significant differences in counts in comparison with control for all microorganisms. However, for P. fluorescens, a lower EEP effect was noted, together with a significant inhibiting effect of E5. As for the pasteurized cow's milk, total bacterial count was $3.80 \log \mathrm{cfu} / \mathrm{mL}$ in raw milk and below $2.18 \log \mathrm{cfu} / \mathrm{mL}$ after the pasteurization. Its results were similar to skim milk, although counts significantly decreased only in P5 for all microorganisms, with the exception of P. fluorescens, and in P2 just in the case of $S$. aureus 25923; apart from $P$. fluorescens, E5 effect was lower of, at least, $1.16 \log \mathrm{cfu} / \mathrm{mL}$ in comparison with P5.

\section{Effect of EEP and ethanol on bacter- ial growth in whey cheese}

Results are shown in Table 3. In cow's product, in P5 L. monocytogenes counts were lower than in control at each time during storage, with differences progressively higher and statistically significant from $\mathrm{t} 14$. In comparison with E5, differences in counts, negligible at $\mathrm{t} 7$, increased in time, showing an inhibiting effect of propolis rather than of ethanol. As for S. aureus, the 2 strains were enumerated together, but the 2 types of colonies were different enough to confirm that the strains were balanced in their growth. EEP didn't obtain significant antibacterial effects; this was probably influenced by the fact that, unsurprisingly, staphylococci didn't grow at $8.5^{\circ} \mathrm{C}$ and even decreased over time, including in control. Anyway, P5 was the most active, with differences of 0.86 (t21) and $0.76 \mathrm{log} \mathrm{cfu} / \mathrm{g}$ (t28) between P5 and E5. Overall, B. cereus showed lower counts than the other bacteria in milk and whey cheese controls. In cow's whey cheese, as for $S$. aureus, counts decreased already in control, with too low values to correctly evaluate the effect of EEP and ethanol. Anyway, at 17 P5 gave rise to 1.90 and $1.38 \log \mathrm{cfu} / \mathrm{g}$ differences versus control and versus E5, respectively. In goat's product, as for $L$. monocytogenes, significant differences versus control were present at $\mathrm{t} 7$ and $\mathrm{t} 14$. Significant differences between P5 and E5 were obtained at $\mathrm{t} 7$, but not at $\mathrm{t} 14$, due to high standard deviations; differences were in both cases higher than 1 $\log \mathrm{cfu} / \mathrm{g}$.

\section{Discussion}

The chemical composition of propolis strictly depends from the plant sources and is a result of geographical location, climate conditions and environmental factors (Bankova et al., 2016). The pollen types found in our propolis were related to the type of vegetation of the geographical environment, with woodland and rural areas. Particularly, chestnut groves were situated within the production area and were responsible for the high content in Castanea pollen. Dry residue of EEP was analogous to that of Gutiérrez-Cortés and SuarezMahecha (2014), and in the range recorded by Cveck et al. (2007) and Barbeira et al. (2013). Flavonoids content was in the range determined by Marghitas et al. (2010) in ethanolic extracts of Romanian propolis. The same authors used EEP to determine the antimicrobial activity with a disk diffusion test on L. monocytogenes, $S$. aureus, $B$. cereus, E. coli and $P$. aeruginosa and obtained inhibition values comparable to ours. Considering EEP MIC values, various authors found results similar to ours: Miorin et al. (2003) obtained values of 0.36-3.65 $\mathrm{mg} / \mathrm{mL}$ for $S$. aureus strains, slightly higher than those of Freitas Santana et al. (2012). More recently, Ristivojević et al. (2016) found MIC of $0.1-1.9 \mathrm{mg} / \mathrm{mL}$ for L. monocytogenes and $0.4-13.7 \mathrm{mg} / \mathrm{mL}$ for $S$. aureus. Finally, Mascheroni et al. (2014) using chitosan-propolis beads found MIC values of $0.8-1 \mathrm{mg} / \mathrm{mL}$ for $S$. aureus, $L$. innocua and $B$. cereus. Our study focused on milk and whey cheese, and, at the best of our knowledge, trials in milk at optimum bacterial temperature and in whey cheese during refrigerated storage were not performed before. Results showed some differences in bacterial behavior in the different growth substrates, but, noteworthily, in all tested matrices, EEP revealed a not negligible antimicrobial effect, higher than that determined by ethanol, particularly against L. monocytogenes.

\section{Conclusions}

The noteworthy antimicrobial activity of propolis, particularly on L. monocytogenes, together with its beneficial properties, could be advantageously exploited, especially in ready-to-eat dairy products to be stored in refrigerated conditions. The development of non-alcoholic formulations (Jansen-Alves et al., 2018) could make it suitable for all consumers.

\section{References}

Baldini M, Fabietti F, Giammarioli S, Onori R, Orefice L, Stacchini A, 1996. Metodi di analisi utilizzati per il controllo chimico degli alimenti. Rapporti ISTISAN 96/34, Istituto Superiore di Sanità, Roma, Italy. ISSN 1123-3117.

Bankova V, Popova M, Trusheva B, 2016. New emerging fields of application of propolis. Maced J Chem Chem Eng 35:1-11.

Banskota AH, Tezuka Y, Kadota S, 2001. Recent progress in pharmacological research of propolis. Phytoter Res 15:561-71.

Barbeira PJS, Paganotti RSN, Ássimos AA, 2013. Development of a multivariate calibration model for the determination of dry extract content in Brazilian commercial bee propolis extracts through UV-Vis spectroscopy. Spectrochim Acta A Mol Biomol Spectrosc 114:441-8.

Chiesa F, Lomonaco F, Nucera D, Garoglio D, Dalmasso A, Civera T, 2014. Distribution of Pseudomonas species in a dairy plant affected by occasional blue discoloration. Ital J Food Saf 9:1722.

Clinical and Laboratory Standards Institute (CLSI), 2013. Performance standards for antimicrobial susceptibility testing; 
twenty-third informational supplement. CLSI document M100-S23. Wayne, PA, USA.

Cveck J, Medić-Sarić M, Jasprica I, Zubčić S, Vitali D, Mornar A, VedrinaDragojević, Tomić S, 2007. Optimisation of an extraction procedure and chemical characterisation of Croatian propolis tinctures. Phytochem Anal 18:451-9.

De Vecchi E, Drago L, 2007. Propolis antimicrobial activity: what's new? Infez Med 15:7-15.

FDA BAM (U. S. Food and Drug Administration Bacteriological Analytical Manual). Bacillus cereus. Available from: https://www.fda.gov/food/laboratorymethods-food/bam-bacillus-cereus Accessed July $28^{\text {th }} 2019$.

Freitas Santana H, Teixeira Barbosa AA, Ferreira SO, Cuquetto Mantovani H, 2012. Bactericidal activity of ethanolic extracts of propolis against Staphylococcus aureus isolated from mastitic cows. World J Microbiol Biotechnol 28:485-91.

Gutiérrez-Cortés C, Suarez Mahecha H, 2014. Antimicrobial activity of propolis and its effect on the physicochemical and sensorial characteristics in sausages. Vitae Columbia 21:90-6.

Heo EJ, Song BR, Park HJ, Kim YJ, Moon JS, Wee SH, Kim JS, Yoon Y, 2014. Rapid detection of Listeria monocytogenes by Real time PCR in processed meat and dairy products. J Food Prot 77:453-8.

Huang S, Zhang C-P, Wang K, Li GQ, Hu F-L, 2014. Recent advances in the chemical composition of propolis. Molecules 19:19610-32.
Jansen-Alves C, Fernandes KF, CrizelCardoso MM, Krumreich FD, Borges CD, Zambiazi RC, 2018. Microencapsulation of propolis in protein matrix using spray drying for application in food systems. Food Bioprocess Tech 11:1422-36.

Louveaux J, Maurizio A, Vorwohl G, 1978. Methods of melissopalynology. Bee World 59:139-57.

Marghitas LA, Mihai CM, Chirila F, Dezmirean DS, Fit N, 2010. The study of the antimicrobial activity of Transylvanian (Romanian) propolis. Not Bot Horti Agrobo 38:40-4.

Mascheroni E, Figoli A, Musatti A, Limbo S, Drioli E, Suevo R, Talarico S, Rollini M, 2014. An alternative encapsulation approach for production of active chitosan-propolis beads. Int $\mathrm{J}$ Food Sci Tech 49:1401-7.

Metwalli SAH, 2011. Extended shelf-life of Kareish cheese by natural preservatives. Egypt. J Agric Res 89:639-49.

Miorin PL, Levy Junior NC, Custodio AR, Bretz WA, Marcucci MC, 2003. Antibacterial activity of honey and propolis from Apis mellifera and Tetragonisca angustula against Staphylococcus aureus. J Appl Microbiol 95:913-20.

Pobiega K, Kraśniewska, K, Gniewosz M, 2019. Application of propolis in antimicrobial and antioxidative protection of food quality - A review. Trends Food Sci Technol 83:53-62.

Popova M, Bankova V, Butovska D, Petkov V, Nikolova-Damianova B, Sabatini AG, Marcazzan GL, Bogdanov S, 2004. Validated methods for the quantification of biologically active constituents of poplar-type propolis. Phytochem Anal
15:235-40.

Ricciardelli D'Albore G, 1979. L'origine géographique de la propolis. Apidologie 10:241-67.

Ristivojević P, Dimkić I, Trifković J, Berić T, Vovk I, Milojković-Opsenica D, Stanković S, 2016. Antimicrobial activity of Serbian propolis evaluated by means of MIC, HPTLC, bioautography and chemometrics. PLoS One 11:e0157097.

Sforcin JM, Bankova V, 2011. Propolis: is there a potential for the development of new drugs? J Ethnopharmacol 133:25360.

Thamnopoulos I-A, Michailidis GF, Fletouris DJ, Badeka A, Kontominas MG, Angelidis AS, 2018. Inhibitory activity of propolis against Listeria monocytogenes in milk stored under refrigeration. Food Microbiol 73:16876.

UNI, 2004. UNI EN ISO 6888-1: 2004. [Microbiologia di alimenti e mangimi per animali - Metodo orizzontale per la conta di stafilococchi coagulasi- positivi (Staphylococcus aureus e altre specie) - Tecnica che utilizza il terreno agar Baird-Parker]. [Regulation in Italian]. Italian Unification Institute ed., Milan, Italy.

Wiegand I, Hilpert K, Hancock RE, 2008. Agar and broth dilution methods to determine the minimal inhibitory concentration (MIC) of antimicrobial substances. Nat Protoc 3:163-75.

Zabaiou N, Fouache A, Trousson A, Baron S, Zellagui A, Lahouel M, Lobaccaro JMA, 2017. Biological properties of propolis extracts; something new from an ancient product. Chem Phys Lipids 207: 214-22. 